\title{
En kløende suvenir
}



Foto: Øystein H. Horgmo, Universitetet i Oslo

En tidligere frisk mann i 40-årene fikk et intenst kløende utslett på baksiden av begge lår åtte uker etter badeferie $\mathrm{i}$ et asiatisk land. Fastlegen mistenkte skabb og forsøkte behandling med permetrin. Pasienten ble ikke bedre og ble derfor henvist til hudlege.

Ved klinisk undersøkelse fant man åtte $3-5 \mathrm{~cm}$ lange, velavgrensede, erytematøse og slangeformede lesjoner lokalisert til baksiden av lårene. Han hadde solt seg på en sandstrand, og lårene var i direkte kontakt med sanden. Diagnosen kutan larva migrans ble diagnostisert på bakgrunn av det kliniske bildet, og pasienten ble behandlet med ivermectin $12 \mathrm{mg}$ som engangsdose. Kløen forsvant etter en dag, og utslettet en uke senere.

Kutan larva migrans forekommer oftest i tropiske og subtropiske strøk. Sykdommen forårsakes av hundens hakeormarter Ancylostoma caninum og Ancylostoma braziliense. Eggene skilles ut i avføringen, og larvene modnes på bakken. Man smittes ved å gå barbeint eller ved annen direkte hudkontakt med sand eller jord, som er forurenset av hundeavføring. Symptomene debuterer innen få dager etter penetrasjon av huden, men inkubasjonstid kan være opptil seks måneder. Larvene kan migrere opptil én $\mathrm{cm}$ daglig, men trenger ikke gjennom hudens basalmembran og forblir i epidermis der de dør i løpet av tre måneder.

Diagnosen baseres på klinisk presentasjon. Lett eosinofili i blodet kan forekomme. Sykdommen er selvbegrensende, men intens kløe nødvendiggjør ofte medikamentell behandling. Antiparasittær behandling med ivermectin er førstevalg, alternativt kan man behandle med albendazole. Lokale kortikosteroider og antihistamin kan brukes for å lindre kløe (1).

Med dagens utstrakte reisevirksomhet til utlandet er dette en sykdom norske leger i økende grad kan komme i kontakt med (2).

Pasienten har gitt samtykke til at artikkelen blir publisert.

\section{Syed Mohammad Husain Rizvi} mohammad.rizvi@ous-hf.no Jan Cezary Sitek

Seksjon for hudsykdommer

Oslo universitetssykehus, Rikshospitalet
Syed Mohammad Husain Rizvi (f. 1983) er lege i spesialisering.

Forfatter har fylt ut ICMJE-skjemaet og oppgir ingen interessekonflikter.

Jan Cezary Sitek (f. 1968) er overlege. Forfatter har fylt ut ICMJE-skjemaet og oppgir ingen interessekonflikter.

\section{Litteratur}

1. Heukelbach J, Feldmeier H. Epidemiological and clinical characteristics of hookworm-related cutaneous larva migrans. Lancet Infect Dis 2008; 8: 302-9.

2. Statistisk sentralbyrå. Reiseundersøkelsen www.ssb.no/transport-og-reiseliv/statistikker/ reise (11.8. 2015)

Mottatt 26.6. 2015, første revisjon innsendt 11.8. 2015, godkjent 11.8. 2015. Redaktør: Lise Mørkved Helsingen. 